Review Article

\title{
Campylobacter pyloridis:a new organism to explain an old problem?
}

\author{
David J. Waghorn
}

Department of Microbiology, Mayday Hospital, Mayday Road, Thornton Heath, Surrey, CR4 7YE, UK.

\section{Introduction}

The discovery of Campylobacter pyloridis and its association with gastritis and peptic ulcer disease has become well established within the last few years. The organism is relatively easy to isolate from biopsy material obtained at endoscopy. Several aspects of the organism's physiology and ability to cause disease have been determined and clinical trials comparing differing treatments are now being conducted.

\section{Historical perspective}

Since the turn of the century, curved or spiral bacteria have been reported from human gastric specimens by several workers. ${ }^{1,2,3}$ However, it was not until 1975 when Steer \& Colin-Jones observed Gram-negative bacteria on the gastric mucosa of $80 \%$ of their patients with gastric ulcers, ${ }^{4}$ that the presence of these organisms was considered possibly associated with active gastritis. In 1979, Warren described campylobacterlike organisms on nearly all gastric mucosal biopsies that he received, ${ }^{5}$ most of which showed histological changes of active chronic gastritis, i.e., infiltration with neutrophils, lymphocytes and plasma cells. This led Warren \& Marshall to perform clinical studies of patients requiring gastroscopy for various symptoms and diseases. They found that curved bacteria were present in virtually all patients and that in $95 \%$ of these, there was histological evidence of active chronic gastritis. ${ }^{6} \mathrm{~A}$ further prospective study demonstrated the presence of the bacteria in $70 \%$ and $90 \%$ of gastric ulcer and duodenal ulcer patients respectively. ${ }^{7}$ By this time the curved bacterium had been successfully isolated as a Gram-negative, microaerophilic organism which has since achieved official recognition as Campylobacter pyloridis. ${ }^{8}$ Now several groups have confirmed the finding of $C$. pyloridis in patients with gastritis and peptic ulcer disease. ${ }^{9-13}$ In this issue of the

Correspondence: D.J. Waghorn M.B., B.S., D.R.C.O.G. Accepted: 27 January 1987
Postgraduate Medical Journal, Sethi et al report on the presence of gastric campylobacter-like organisms in $91 \%$ of patients with chronic superficial gastritis ${ }^{14}$ which is in close agreement with other studies. Most importantly, they did not detect the organism histologically in any patient with a normal gastric mucosa.

\section{Campylobacter pyloridis, gastritis and peptic ulcer}

The source of $C$. pyloridis infection is unknown. Curved bacteria colonise the gut of several animals ${ }^{15}$ but despite lengthy search, they have not been found in other parts of the human alimentary tract. ${ }^{16}$ How does the organism cause gastritis? C. pyloridis is now known to belong to a group of bacteria that can adapt to a mucus environment. Their corkscrew movement enables them to penetrate and pass freely in viscous solutions which other bacteria such as Escherichia coli find restrictive. ${ }^{17}$ Having penetrated gastric mucus and under the influence of chemotactic stimuli, they move towards the gastric epithelium and in particular to intercellular junctions between gastric epithelial cells where the highest concentration of potential nutrients/growth factors such as urea and haemin diffuse out. $C$. pyloridis produces a large amount of urease (estimated to be 1000 times greater than Proteus vulgaris ${ }^{18}$ ) which splits the urea to produce ammonia with a subsequent increase in local $\mathrm{pH}$ that also promotes multiplication of the organism. $C$. pyloridis attracts and activates neutrophils: ${ }^{19}$ this may occur via an action on local complement components by the bacterium leading to the release of substances chemotactic to leucocytes. ${ }^{20}$ Inflammation and gastritis result with the following histological and pathophysiological changes: ${ }^{21}$ (a) adherence pedestals between organism and epithelial cell, (b) depletion of microvilli, (c) disruption of supporting microfilaments within epithelial cells, (d) decrease in mucus production and (e) hypochlorhydria. 
How may C. pyloridis infection further progress to peptic ulceration? In some patients, for reasons not fully understood, acute infection by the organism is not cleared by normal immune mechanisms leading to a chronic phase. ${ }^{22}$ The rapid hydrolysis of urea results in the formation of ammonia which causes coupling of hydrogen ions to form ammonium ions producing hypoacidity and secondly, a direct toxic affect on the gastric mucosa via depletion of ATP. ${ }^{18}$ These events together with disruption of mucus production predispose to ulcer formation when acid and other luminal factors such as pepsin reach the damaged mucosa.

\section{Antibody response and measurement}

Antibody production against $C$. pyloridis has been studied by several groups. Serum complement fixation, haemagglutination and bacterial agglutination tests have all been reported with raised titres found in bacteria positive patients. ${ }^{23}$ Enzyme linked immunosorbent assay (ELISA) techniques recently developed have also shown significantly raised serum IgG and IgA titres to $C$. pyloridis. ${ }^{24}$ In this journal, Sethi et al. demonstrate the presence of antibodies by both complement fixation and ELISA techniques. ${ }^{14}$ In those patients with histological evidence of gastritis, $77 \%$ had significant titres of antibody to the organism whereas all those with normal histology failed to show a raised antibody level. Although circulating IgG antibodies are necessary in preventing systemic invasion, it is local secretory IgA levels which are more important for mucosal surface immunity. An ELISA method has also been used to show detectable titres of IgA to $C$. pyloridis in the gastric juices of patients with gastritis. ${ }^{25}$ These antibodies do not eliminate the infection or prevent colonisation but they may lessen bacterial adherence and invasion.

\section{Diagnosis of $C$. pyloridis infection}

How is C. pyloridis infection diagnosed? The organism can be detected in fixed sections of biopsy material through different staining processes. Routine haematoxylin and eosin will stain any bacteria present but a silver stain such as Warthin-Starry is superior. ${ }^{5}$ Other techniques used include phase contrast microscopy, fluorescent labelling with acridine-orange and a modified Giemsa stain, the latter giving an especially rapid, simple and reliable result. ${ }^{26} \mathrm{~A}$ polyclonal antibody raised in rabbits has also been used to label $C$. pyloridis in tissue sections ${ }^{27}$ and electron microscopy has been particularly helpful in illustrating the organism's ultrastructure and its relationship to the gastric mucosa. ${ }^{28}$

The microbiological identification of $C$. pyloridis involves staining, detecting urease activity and culturing from biopsy tissue with a combination of these methods diagnosing almost all infections. Grame stained smears taken directly from tissue will often:demonstrate the curved bacteria. ${ }^{29}$ The great ability of: C. pyloridis to split urea, a feature not seen in othero campylobacters affecting man, ${ }^{26}$ is now being used to음 specifically diagnose colonization. Homogenized gas $-\frac{\bar{n}}{7}$ tric biopsies may be left in a urea broth at room temperature for 24 hours, but up to $50 \%$ of positive specimens will produce a colour change within ${ }^{\text {s }}$ 6 hours. $^{30}$

C. pyloridis was first isolated using campylobacterlike isolation techniques ${ }^{31}$ but it has since been shown to grow on nearly any basic media supplemented witho blood or serum..$^{29}$ On a suitable media, the organism 3 will grow within 3 days in humid microaerophilico conditions at $37^{\circ} \mathrm{C}$ or $42^{\circ} \mathrm{C}$ to produce small circular translucent colonies. Interestingly, the morphology of $\triangle$ the bacteria in pure culture differs from that seen in their primary tissue. In culture, bizarre U-shaped or circulare cells and rod-like forms are often observed $;{ }^{29}$ this mayo indicate that ideal conditions for in vitro growth havenot yet been found.

\section{Comparison with other campylobacters}

Although $C$. pyloridis has been officially recognizedo and named as a member of the campylobacter genus, there are fundamental differences between $C$. pyloridis and other species. (1) $C$. pyloridis possesses multiple unipolar sheathed flagella with terminal bulbs and ${ }^{Q}$ has a smooth cell wall whereas other species have a흘 single unsheathed flagellum lacking a terminal bulb; they also have a rough surface. ${ }^{28}(2)$ Polyacrylamide gel electrophoresis patterns show differences between protein composition. ${ }^{32}$ (3) Cellular fatty acid content? differs considerably between $C$. pyloridis and other:species. ${ }^{28}(4) C$. pyloridis lacks the respiratory quinone, $\overline{3}$ methylated menaquinone- 6 which is found in all other. members of the genus. ${ }^{33}(5) C$. pyloridis produces at least 3 powerful enzymes in large amounts e.g. urease, ${ }^{34}$ superoxide dismutase and catalase ${ }^{35}$ which 9 other species either do not produce or do so in much less quantity. Support for the organism being recognized as a campylobacter lies in its general shape, $N$ growth requirements and perhaps more significantly, $\mathrm{N}$ from the DNA base composition of guanine plus cytosine $35.8-37.1 \mathrm{~mol} \%^{31}$ being within the cam- $\omega$ pylobacter range.

\section{In vitro sensitivity of $C$. pyloridis}

The isolation of $C$. pyloridis has naturally led to in vitro $\frac{0^{\circ}}{\mathbb{C}}$ antibiotic sensitivity testing. The organism appears $\frac{\stackrel{9}{\odot}}{8}$ 
sensitive to penicillin, amoxycillin, erythromycin, cephalothin, tetracycline, gentamicin and metronidazole but resistant to vancomycin, trimethoprim, sulphamethoxazole and nalidixic acid. ${ }^{26,36}$ The fact that $C$. pyloridis may play a significant role in peptic ulcer disease, has led to the measurement of the antibacterial activity of drugs currently used for this condition. The minimal inhibitory concentrations (MICs) of bismuth salts against $C$. pyloridis are in the range $4-32 \mathrm{mg} / 1,{ }^{37}$ which is much lower than that for other ulcer healing drugs such as cimetidine, carbenoxolone or sucralfate. ${ }^{36,37}$

\section{In vivo effect of anti-ulcer drugs}

It has been known for some time that gastric acid is the major precipitating cause of peptic ulceration and that inflammation and in particular active chronic gastritis produces the initial pathological changes which allow subsequent damage by acid. ${ }^{38,39}$ The inhibition of acid production by either histamine- $2\left(\mathrm{H}_{2}\right)$ receptor antagonists or proton pump inhibitors, though producing ulcer healing, does not remove either the inflammation ${ }^{40}$ or the colonization with $C$. pyloridis. The same applies to those ulcers treated with carbenoxolone or sucralfate $\mathrm{e}^{41,42}$ and this may explain why patients with peptic ulcers treated with such drugs have a higher relapse rate than those treated with bismuth compounds. ${ }^{43,}{ }^{44}$ Indeed it is believed that cimetidine may actually promote relapse by raising intragastric $\mathrm{pH}$ to provide an environment conducive to bacterial growth. ${ }^{45}$ Histological evidence has confirmed that bismuth compounds both eradicate $C$. pyloridis in vivo and greatly improve the gastritis. Marshall et al. have also demonstrated via electron microscopy that bismuth can coat $C$. pyloridis in gastric pits resulting in swelling and eventual lysis of the organisms. ${ }^{46}$

Controlled clinical trials comparing different treatments for $C$. pyloridis infection have just begun. One of the first such studies has recently been published comparing the efficacy of bismuth, erythromycin and placebo in the treatment of $C$. pyloridis associated gastritis. ${ }^{47}$ Bismuth proved very successful in eradicating the bacteria and improving the histological picture. In contrast, infection persisted in all but one case given erythromycin. The probable explanation was that erythromycin had been given in an inactive ester form which had no topical activity within the stomach, required absorption from the small intestine, hydrolysis to the active base and diffusion back through gastric mucosa to the crypts and mucus in order to reach its target organism; it is therefore likely that whilst inhibitory levels of bismuth were obtained at the gastric epithelium, insufficient concentrations of erythromycin were achieved at the same site. Amoxycillin, which is already known to eliminate $C$. pyloridis in vivo, may be a more suitable choice of antibiotic to use either alone or in combination with a bismuth compound which is likely to be the best treatment of all. ${ }^{41,42}$

Many gastroenterologists remain to be convinced of the role of $C$. pyloridis in gastritis and peptic ulcer. Their main reservations stem from the finding that the organism is sometimes found in patients with few dyspeptic symptoms but with histological gastritis, yet can be absent in those complaining of dyspepsia who have a normal mucosa. However, when gastritis and C. pyloridis do occur together, the symptoms produced, the abdominal pain, epigastric burning, halitosis, nausea and distension, are very consistent.

Goodwin et al. have reported on the case of a 64 year old woman previously labelled as suffering from nervous dyspepsia since the age of $18 .^{21}$ Initial gastroscopy in this lady revealed a macroscopically normal stomach but microscopic examination of biopsy material showed severe active chronic gastritis together with $C$. pyloridis. Two weeks of bismuth treatment improved symptoms quickly and biopsies taken at 4 and 8 weeks were negative for the bacterium. However after a further 3 weeks, her problem returned and another biopsy revealed inflammation together with $C$. pyloridis again. A second course of therapy combined 4 weeks of bismuth with 3 weeks of oral amoxycillin. Symptoms again disappeared within a few days and this time gastric tissue samples taken at 1 and 6 months showed histologically normal mucosa, C. pyloridis was not grown and the patient had remained well for 2 years subsequently.

\section{Conclusions}

The last case report is but one example of the extremely strong evidence which has built up for the association of $C$. pyloridis with gastritis and peptic ulcer disease. However, C. pyloridis is only one of a number of factors which have received much attention and investigation in this field recently. Prostaglandins for example have been shown to exert several different mucosal protective effects including inhibition of acid secretion and increasing bicarbonate secretion. ${ }^{48}$ Further research lies ahead in order to determine more clearly how $C$. pyloridis causes disease and which forms of treatment will give the best results. In a recent popular publication, the following passage appeared: 'Peptic ulcer is a chronic relapsing disorder. Medical therapy does not alter the underlying ulcer diathesis and only an effective acid-reducing operation cures peptic ulcer disease. ${ }^{49}$ It seems therefore that there is still some way to go to fully prove the role of $C$. pyloridis in upper gastrointestinal disease and perhaps this should be the main aim for the near future. 
1. Krienitz, W. Ueber das auftreten von mageninhalt bei carcinoma ventriculi. Dtsch Med Wochenschr 1906, 22: 872.

2. Rosenow, E.C., Sandford, A.H. The bacteriology of ulcer of the stomach and duodenum in man. $J$ Infect Dis 1915, 17: 210-226.

3. Doenges, J.L. Spirochaetes in the gastric glands of Macacus rhesus and of man without related disease. Arch Pathol 1939, 27: 469-477.

4. Steer, H.W. \& Colin-Jones, D.G. Mucosal changes in gastric ulceration and their response to carbenoxolone sodium. Gut 1975, 16: 590-597.

5. Warren, J.R. Unidentified curved bacilli on gastric epithelium in active chronic gastritis. Lancet 1983, i: 1273.

6. Marshall, B.J. \& Warren, J.R. Unidentified curved bacilli in the stomach of patients with gastritis and peptic ulceration. Lancet 1984, i: 1311-1315.

7. Marshall, B.J., McGechie, D.B., Rogers, P.A. \& Glancy, R.J. Pyloric campylobacter infection and gastroduodenal disease. Med J Austr 1985, 142: 439-444.

8. Anonymous. Validation of publication of new names and new combinations previously effectively published outside the IJSB. Inst J Syst Bacteriol 1985, 85: 223-225.

9. McNulty, C.A.M. \& Watson, D.M. Spiral bacteria of the gastric antrum. Lancet 1984, i: 1068-1069.

10. Jones, D.M., Lessells, A.M. \& Eldridge, J. Campylobacter like organisms on the gastric mucosa: culture, histology and serological studies. J Clin Pathol 1984, 37: 1002-1006.

11. Phillips, A.D., Hine, K.R., Holmes, G.K.T. \& Woodings, D.F. Gastric spiral bacteria. Lancet 1984, ii: 100-101.

12. Price, A.B., Leui, J., Dolby, J.M. et al. Campylobacter pyloridis in peptic ulcer disease: microbiology, pathology and scanning electron microscopy. Gut 1985, 26: 11831188.

13. Steer, H.W. The gastroduodenal epithelium in peptic ulceration. J Pathol 1985, 146: 355-362.

14. Sethi, P., Banerjee, A.K., Jones, D.M., Eldridge, J. \& Hollanders, D. Gastritis and gastric campylobacter-like organisms in endoscopically normal patients. Postgrad Med J 1987, 63: 543-545

15. Lee, A. Neglected niches: the microbial ecology of the gastrointestinal tract. In Marshall, K.C. (ed). Advances in Microbial Ecology. Plenum Publishing, New York, 1985, vol 8, pp. 115-162.

16. Editorial. Campylobacters in Ottawa. Lancet 1985, ii: 135.

17. Hazell, S.L., Lee, A., Brady, L. \& Hennessy, W. Campylobacter pyloridis and gastritis: association with intercellular spaces and adaptation to an environment of mucus as important factors in colonisation of the gastric epithelium. J Infect Dis 1986, 153 (4): 658-663.

18. Hazell, S.L. \& Lee, A. Campylobacter pyloridis, urease, hydrogen ion back diffusion and gastric ulcers. Lancet 1986, ii: $15-17$.

19. Shousha, S., Bull, T.B. \& Parkins, R.A. Gastric spiral bacteria. Lancet 1984, ii: 101.

20. Hazell, S.L. \& Lee, A. Campylobacter pyloridis, urease and gastric ulcers. Lancet 1986, ii: 626 .

21. Goodwin, C.S., Armstrong, J.A., Marshall, B.J. Campylobacter pyloridis, gastritis and peptic ulceration. $J$
Clin Pathol 1986, 39: 353-365.

22. Marshall, B.J., Armstrong, J.A., McGechie, D.B., Glan-. cy, R.J. Attempt to fulfil Koch's postulates for pyloric $\overrightarrow{\overline{\vec{C}}}$ campylobacter. Med J Austr 1985, 142: 436-439.

23. Marshall, B.J., McGechie, D.B., Francis, G.J. \&음 Utley, P.J. Pyloric campylobacter serology. Lancet 1984, 음 ii: 281 .

24. Rathbone, B.J., Wyatt, J.I., Worsley, B.W., Trejdosie- $\overparen{\Phi}$ wicz, L.K., Heatley, R.V. \& Losowsky, M.S. Immune response to Campylobacter pyloridis. Lancet 1985, i: 1217.

25. Rathbone, B.J., Wyatt, J.I. \& Worsley, B.W. et al. Systemic and local antibody response to gastric Cam- $\vec{\omega}$ pylobacter pyloridis in nonulcer dyspepsia. Gut 1986, 27: 642-647.

26. Rathbone, B.J., Wyatt, J.I. \& Heatley, R.V. Campy-3 lobacter pyloridis - a new factor in peptic ulcer disease? Gut 1986, 27: 635-641.

27. Steer, H.W. \& Newell, D.G. Immunological identifica- $\$ tion of Campylobacter pyloridis in gastric biopsy tissue. Lancet 1985, ii: 38.

28. Goodwin, C.S., McCulloch, R.K., Armstrong, J.A. \& Wee, S.H. Unusual cellular fatty acids and distinctive ultrastructure in a new spiral bacterium (Campylobacter $\overrightarrow{-}$ pyloridis) from the human gastric mucosa. J Med $\cong$ Microbiol 1985, 19: 257-267.

29. Buck, G.E., Gourley, W.K., Lee, W.K., Subraman- $\vec{c}$ yam, K., Latimer, J.M. \& Dinuzzo, A.R. Relation gif $_{V}^{\infty}$ Campylobacter pyloridis to gastritis and peptic ulcer $J$ Infect Dis 1986; 153 (4): 664-669.

30. McNulty, C.A.M. \& Wise, R. Rapid diagnosis of cam pylobacter associated gastritis. Lancet 1985 , i: $1443-$ 1444.

31. Marshall, B.J. Unidentified curved bacilli on gastric epithelium in active chronic gastritis. Lancet 1983, i: 1273-1275.

32. Pearson, A.D., Ireland, A., Bamforth, J. et al. Polyacrylamide gel electrophoresis of spiral bacteria from the gastric antrum. Lancet 1984, i: 1349-1350.

33. Marshall, B.J. Campylobacter pyloridis and gastritis. $J 0$ Infect Dis 1986; 153 (4): 650-657.

34. Langenburg, M.L., Tytgat, G.N., Schipper, M.E., Rietra, P.J. \& Zanen, H.C. Campylobacter like organisms in the

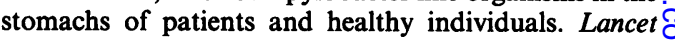
1984, i: 1348.

35. Lior, H. \& Johnson, W.N. Catalase, peroxidase and 0 superoxide dismutase activities in campylobacter species. In Pearson, A.D., Skirrow, M.B., Lior, H. (eds) Cam- $\frac{D}{O}$ pylobacter III: Proceedings of the Third International Workshop on Campylobacter Infections. Public Health N Laboratory Service, London, 1985, pp. 226-227.

36. Lambert, J.R., Hansky, J., Davidson, A., Pinkard, K. \& N Stockman, K. Campylobacter like organisms (CLO)-in N vivo and in vitro susceptibility to antimicrobial and $\sigma$ antiulcer therapy. Gastroenterology 1985, 88: 1462.

37. McNulty, C.A.M., Dent, J. \& Wise, R. Susceptibility of $\frac{\text { 을 }}{2}$ clinical isolates of Campylobacter pyloridis to eleven $\mathbb{E}$ antimicrobial agents. Antimicrob Agents Chemother: 1985, 28: 837-838.

38. Mackay, I.R. \& Hislop, I.G. Chronic gastritis and gastric ulcer. Gut 1966, 7: 228-233. 
39. Schrager, J., Spink, R. \& Mitra, S. The antrum in patients with duodenal and gastric ulcers. Gut 1967, 8: 497-508.

40. Fullman, G., Van Deventer, C., Schmidman, D., Walsh, J., Elashoff, J. \& Weinstein, W. 'Healed' duodenal ulcers are histologically ill. Gastroenterology 1985, 88: 1390.

41. Jones, D.M., Eldridge, J., Whorwell, P.J. \& Miller, J.P. The effects of various antiulcer regimens and antibiotics on the presence of Campylobacter pyloridis and its antibody. In: Pearson, A.D., Skirrow, M.B. \& Lior, H. (eds) Campylobacter III. Proceedings of the Third International Workshop on Campylobacter Infections. Public Health Laboratory Service, London, 1985, p. 161.

42. Langenburg, M.L., Rauws, E.A., Schipper, M.E. et al. The pathogenic role of Campylobacter pyloridis studied by attempts to eliminate these organisms. In Pearson, A.D., Skirrow, M.B. \& Lior, H. (eds) Campylobacter III. Proceedings of the Third International Workshop on Campylobacter Infections, Public Health Laboratory Service, London, 1985, pp. 162-163.

43. Martin, D.F., Hollanders, D., May, S.J., Ravenscroft, M.M., Tweedle, D.E. \& Miller, J.P. Difference in relapse rates of duodenal ulcer after healing with cimetidine or tripotassium dicitrato bismuthate. Lancet 1980, i: 7-10.

44. MacLean, A.J., Harrison, P.M., Ioannides-Demos, L.,
Byrne, A.J., McCarthy, P. \& Dudley, F.J. The choice of ulcer healing agent influences duodenal ulcer relapse rate and long term clinical outcome. Aust NZ J Med 1985, 15: 367-374.

45. MacLean, A.J., Harrison, P.M., Ioannides-Demos, L., Byrne, A.J., McCarthy, P. \& Dudley, F.J. Microbes, peptic ulcer and relapse rates with different drugs. Lancet 1984, ii: 525-526.

46. Marshall, B.J., McGechie, D.B., Armstrong, J.A. \& Francis, G. The antibacterial action of bismuth: early results using antibacterial regimens in the treatment of duodenal ulcer. In Pearson, A.D., Skirrow, M.B. \& Lior, H. (eds) Campylobacter III. Proceedings of the Third International Workshop on Campylobacter Infections. Public Health Laboratory Service, London, 1985, pp. 165-166.

47. McNulty, C.A.M., Gearty, J.C., Crump, B. et al. Campylobacter pyloridis and associated gastritis: investigator blind, placebo controlled trial of bismuth salicylate and erythromycin ethylsuccinate. $\mathrm{Br}$ Med J 1986, 293: 645649.

48. Colin-Jones, D.G. There is more to healing ulcers than suppressing acid. Gut 1986, 27: 475-480.

49. Anonymous. Peptic ulcer: which patients to consider for surgery. Drugs Ther Bull 1986, 24 (20): 77-78. 